\title{
THE EFFECT OF HERBICIDES AND SURFACTANTS ON TURF GRASSES AND ANNUAL POA
}

\author{
M.P. FINLAYSON ${ }^{1}$ and F. DASTGHEIB ${ }^{2}$ \\ ${ }^{1}$ Otago Polytechnic, P O Box 16, Cromwell \\ ${ }^{2}$ Lincoln University, $P$ O Box 2, Canterbury
}

\begin{abstract}
The tolerance of browntop (Agrostis capillaris L.), perennial ryegrass (Lolium perenne L.), Chewings fescue (Festuca nigrescens Lam.) and annual poa (Poа аппиа L.) to twelve herbicides, with and without two organosilicone surfactants (Silwet L77 and Silwet S800), were assessed. Annual poa was controlled by haloxyfop and clethodim plus S800. Browntop was highly tolerant to chlorsulfuron and metsulfuron, and Chewings fescue to haloxyfop, fluazifop, clethodim and sethoxydim. Organosilicone surfactants affected the tolerance of some species to certain herbicides. For example, Silwet L77 reduced the tolerance of annual poa to glyphosate but S800 increased the tolerance of perennial ryegrass to terbuthylazine. The results have implications for the management of cool season turf.
\end{abstract}

Keywords: adjuvants, browntop, fescue, sportsfields, weed management.

\section{INTRODUCTION}

The main cool season turf species used in New Zealand are browntop (Agrostis capillaris L.), perennial ryegrass (Lolium perenne L.) and Chewings fescue (Festuca nigrescens Lam.). Grass weeds, more so than broadleaf weeds, are the major weed problems in cool season turf grasses as they are very similar to the main turf species in their tolerance to herbicides. Annual poa (Poa annua L.) has long been one of the main grass weed species of most New Zealand turf grounds (McLean 1978). Annual poa frequently invades, persists and becomes the major component of irrigated, close cut, intensely fertilised turf and is generally regarded as the main grass weed problem in cool season sports turf throughout the world (Beard 1973).

Over several decades various chemical treatments have been used to control annual poa in cool season turf. These include sulphur (Goss et al. 1975), arsenicals, DCPA, benefin, bensulide, paclobutrazol, endothal, ethofumesate, prodiamine (Vargas 1990; Baldwin 1993; Dernoeden 1998; Glasgow 1991) and different plant growth regulators (Johnson and Murphy 1996; Fagerness and Penner 1998). More recently a number of new herbicides have been developed for selective control of grass weeds in broadleaf crops. These include clethodim, fluazifop-butyl, haloxyfop and sethoxydim. These herbicides have label claims that Chewings fescue is a tolerant species (Fussell and Walton 1997), although little if any experimental work has been carried out on the tolerance of Chewings fescue sports turf cultivars in New Zealand to these herbicides.

It is known that surfactants affect the performance of herbicides and may vary the margin of selectivity between weeds and desired plants. The introduction of the organosilicone surfactants has opened up new opportunities for the efficient delivery of pesticide active ingredients into the plant (Field and Dastgheib 1996). It has been reported that the addition of Silwett L77 enhanced the uptake of glyphosate in pampas grass (Cortaderia spp.), gorse (Ulex europeus L.) and perennial ryegrass (Dastgheib et al. 1994; Field and Bishop 1988; Gaskin and Zabkiewicz 1992). On the other hand Silwett L77 decreased glyphosate uptake in paspalum (Paspalum dilatatum L.) and couch (Elytrigia repens Beauv.) (Field et al. 1992). 
This study was designed to investigate the effect of several herbicides with and without the addition of two organosilicone surfactants on the tolerances of four grass species. The aim was to find chemical treatments which selectively remove annual poa from browntop, Chewings fescue and perennial ryegrass turf.

\section{MATERIALS AND METHODS}

Three pot experiments were conducted in a greenhouse at minimum/maximum temperatures of $16 / 25^{\circ} \mathrm{C}$ to test the tolerance of browntop, perennial ryegrass, Chewings fescue and annual poa to different postemergence herbicide treatments. Plants were obtained from turf grounds using a core sampler $14.8 \mathrm{~mm}$ in diameter and $75 \mathrm{~mm}$ in length. The cores were planted into $50 \times 50 \times 80 \mathrm{~mm}$ pots at one core per pot filled with a Waimakariri silt loam soil. Plants were given sufficient time (between 4 and 6 weeks) to establish before receiving treatments. All plants were cut to a height of $75 \mathrm{~mm}$ one week before spraying. Plants were sprayed using a sprayer cabinet with a pressure of $320 \mathrm{kPa}$ delivering 300 litres water/ha.

The first experiment compared 12 herbicides each at two rates with and without the addition of each of the organosilicone surfactants Silwet L77 and Silwet S800 (hereafter referred to as $\mathrm{L} 77$ and S800, respectively) at $0.1 \%$ concentration. This made a total of 72 treatments and one untreated control in a split plot design (herbicides as the main plots) with three replicates. Herbicide names are given in Table 1. Plants were assessed visually at 3,6 and 12 weeks after treatment (WAT) and given a score of 1 (healthy) to 10 (dead). Plants were harvested 12 WAT and their dry weights determined.

The second experiment studied the effect of five of the most promising herbicides on the same species as the first trial. Three herbicides namely isoproturon plus diflufenican, terbuthylazine and haloxyfop were used at one rate, amitrole was used at two rates and glyphosate at three rates (Fig. 1). All herbicide treatments were used with and without the addition of the organosilicone surfactant S800 at $0.1 \%$. This experiment had a randomised complete block design with five replicates.

The third experiment studied the effect of glyphosate and surfactants on the control of annual poa in more detail. There were three rates of glyphosate with and without each of the organosilicone surfactants L77 and S800 at $0.1,0.25$ and $0.5 \%$ concentrations. The experimental design was a randomised complete block with four replicates. All data were subjected to analysis of variance using Genstat 4.1 and means were separated by LSD $(\mathrm{P}<0.05)$.

\section{Experiment 1}

\section{RESULTS}

Regular visual assessments of plants in the first experiment showed differential tolerance between grass species to the herbicides. As the response trend to treatments followed the same pattern, only the last assessment at 12 WAT is reported here (Table 1). Moreover, only the higher rate of herbicides is presented for brevity.

Chewings fescue showed high tolerance to haloxyfop, fluazifop, clethodim and sethoxydim while browntop and ryegrass were sensitive to them (Table 1). Annual poa was tolerant to fluazifop and sethoxydim but was controlled by haloxyfop on its own and by clethodim with S800. Perennial ryegrass was very sensitive to clethodim and sethoxydim either with or without the organosilicone surfactants. Chlorsulfuron and metsulfuron were reasonably safe on browntop but killed perennial ryegrass, although the addition of the surfactant L77 reduced the effect of metsulfuron on perennial ryegrass.

All grass species showed a high level of tolerance to amitrole at $200 \mathrm{~g} / \mathrm{ha}$ and the addition of surfactants did not affect their responses (Table 1). Annual poa showed initial damage 3 weeks after application of amitrole (data not shown) but it had recovered by 12 weeks. The effect of ethofumesate was stronger on Chewings fescue than on annual poa irrespective of the surfactants. Terbuthylazine on its own or with the addition of L77 killed all species tested. When S800 was added, the effect of 
terbuthylazine on perennial ryegrass was reduced significantly while it provided complete control of annual poa. Similarly, isoproturon plus diflufenican with the addition of S800 gave good control of annual poa without significant damage to perennial ryegrass or Chewings fescue. These combinations may be promising for the control of annual poa in perennial ryegrass turf. All grass species with the exception of annual poa showed high tolerance to glyphosate at $180 \mathrm{~g} / \mathrm{ha}$. Glyphosate caused significant damage to poa either on its own or with the surfactants, although there was some regrowth after 12 weeks.

TABLE 1: Visual assessment ${ }^{1}$ of turf grasses 12 weeks after treatment in experiment 1.

\begin{tabular}{|c|c|c|c|c|c|c|}
\hline $\begin{array}{l}\text { Herbicide } \\
\text { (Trade name) }\end{array}$ & $\begin{array}{r}\text { Rate } \\
\mathrm{g} \text { ai/ha }\end{array}$ & Surfactant & Browntop & $\begin{array}{c}\text { Annual } \\
\text { poa }\end{array}$ & $\begin{array}{c}\text { Perennial } \\
\text { ryegrass }\end{array}$ & $\begin{array}{l}\text { Chewings } \\
\text { fescue }\end{array}$ \\
\hline $\begin{array}{l}\text { Haloxyfop } \\
\text { (Gallant ) }\end{array}$ & 300 & $\begin{array}{l}0 \\
\text { L77 } \\
\text { S800 }\end{array}$ & $\begin{array}{r}10.0 \\
8.7 \\
9.7\end{array}$ & $\begin{array}{r}10.0 \\
6.3 \\
7.7\end{array}$ & $\begin{array}{r}9.7 \\
10.0 \\
8.3\end{array}$ & $\begin{array}{l}1.0 \\
1.0 \\
1.0\end{array}$ \\
\hline $\begin{array}{l}\text { Fluazifop } \\
\text { (Fusilade) }\end{array}$ & 375 & $\begin{array}{l}0 \\
\text { L77 } \\
\text { S800 }\end{array}$ & $\begin{array}{l}4.7 \\
8.7 \\
4.0\end{array}$ & $\begin{array}{l}1.0 \\
1.0 \\
1.0\end{array}$ & $\begin{array}{r}8.7 \\
10.0 \\
2.3\end{array}$ & $\begin{array}{l}1.0 \\
1.0 \\
1.0\end{array}$ \\
\hline $\begin{array}{l}\text { Clethodim } \\
\text { (Centurion) }\end{array}$ & 240 & $\begin{array}{l}0 \\
\mathrm{~L} 77\end{array}$ & $\begin{array}{l}8.3 \\
7.7\end{array}$ & $\begin{array}{l}2.0 \\
6.7\end{array}$ & $\begin{array}{l}10.0 \\
10.0\end{array}$ & $\begin{array}{l}1.0 \\
1.0\end{array}$ \\
\hline & & S800 & 9.3 & 9.0 & 10.0 & 1.0 \\
\hline $\begin{array}{l}\text { Sethoxydim } \\
\text { (Poast) }\end{array}$ & 372 & $\begin{array}{l}0 \\
\text { L77 } \\
\text { S800 }\end{array}$ & $\begin{array}{l}9.0 \\
9.3 \\
8.3\end{array}$ & $\begin{array}{l}1.0 \\
1.0 \\
1.0\end{array}$ & $\begin{array}{l}10.0 \\
10.0 \\
10.0\end{array}$ & $\begin{array}{l}1.0 \\
1.0 \\
1.0\end{array}$ \\
\hline $\begin{array}{l}\text { Chlorsulfuron } \\
\text { (Glean) }\end{array}$ & 30 & $\begin{array}{l}0 \\
\text { L77 } \\
\text { S800 }\end{array}$ & $\begin{array}{l}2.0 \\
2.0 \\
2.3\end{array}$ & $\begin{array}{l}2.0 \\
2.0 \\
1.3\end{array}$ & $\begin{array}{l}10.0 \\
10.0 \\
10.0\end{array}$ & $\begin{array}{l}2.7 \\
5.3 \\
2.7\end{array}$ \\
\hline $\begin{array}{l}\text { Metsulfuron } \\
\text { (Escort) }\end{array}$ & 30 & $\begin{array}{l}0 \\
\text { L77 } \\
\text { S800 }\end{array}$ & $\begin{array}{l}1.7 \\
1.3 \\
1.7\end{array}$ & $\begin{array}{l}1.7 \\
2.0 \\
2.7\end{array}$ & $\begin{array}{r}9.3 \\
5.7 \\
10.0\end{array}$ & $\begin{array}{l}5.7 \\
6.7 \\
7.7\end{array}$ \\
\hline $\begin{array}{l}\text { Amitrole } \\
\text { (Amitrole) }\end{array}$ & 200 & $\begin{array}{l}0 \\
\text { L77 } \\
\text { S800 }\end{array}$ & $\begin{array}{l}2.7 \\
2.0 \\
2.7\end{array}$ & $\begin{array}{l}2.3 \\
2.0 \\
2.7\end{array}$ & $\begin{array}{l}2.0 \\
2.0 \\
1.7\end{array}$ & $\begin{array}{l}1.0 \\
2.0 \\
1.3\end{array}$ \\
\hline $\begin{array}{l}\text { Ethofumesate } \\
\text { (Nortron) }\end{array}$ & 2000 & $\begin{array}{l}0 \\
\text { L77 } \\
\text { S800 }\end{array}$ & $\begin{array}{l}2.7 \\
2.0 \\
2.3\end{array}$ & $\begin{array}{l}2.3 \\
2.0 \\
1.7\end{array}$ & $\begin{array}{l}2.0 \\
4.0 \\
2.0\end{array}$ & $\begin{array}{l}7.0 \\
6.7 \\
7.7\end{array}$ \\
\hline $\begin{array}{l}\text { Terbuthylazine } \\
\text { (Gardoprim) }\end{array}$ & 1500 & $\begin{array}{l}0 \\
\text { L77 } \\
\text { S800 }\end{array}$ & $\begin{array}{l}10.0 \\
10.0 \\
10.0\end{array}$ & $\begin{array}{l}10.0 \\
10.0 \\
10.0\end{array}$ & $\begin{array}{r}10.0 \\
9.3 \\
5.3\end{array}$ & $\begin{array}{r}9.3 \\
10.0 \\
9.3\end{array}$ \\
\hline $\begin{array}{l}\text { Isoproturon } \\
\text { (Graminon) }\end{array}$ & 390 & $\begin{array}{l}0 \\
\text { L77 } \\
\text { S800 }\end{array}$ & $\begin{array}{l}5.0 \\
7.3 \\
4.0\end{array}$ & $\begin{array}{l}5.3 \\
7.0 \\
3.0\end{array}$ & $\begin{array}{l}4.0 \\
9.0 \\
1.7\end{array}$ & $\begin{array}{l}1.7 \\
1.7 \\
2.0\end{array}$ \\
\hline $\begin{array}{l}\text { Isoproturon and } \\
\text { diflufenican } \\
\text { (Cougar) }\end{array}$ & $\begin{array}{r}1000 \\
\text { and } 200\end{array}$ & $\begin{array}{l}0 \\
\text { L77 } \\
\text { S800 }\end{array}$ & $\begin{array}{l}7.0 \\
6.0 \\
6.7\end{array}$ & $\begin{array}{l}6.0 \\
9.0 \\
9.0\end{array}$ & $\begin{array}{r}7.0 \\
10.0 \\
3.0\end{array}$ & $\begin{array}{l}1.3 \\
1.0 \\
1.3\end{array}$ \\
\hline Glyphosate & 180 & $\begin{array}{l}0 \\
\text { S800 }\end{array}$ & $\begin{array}{l}3.0 \\
3.0\end{array}$ & $\begin{array}{l}6.7 \\
6.7\end{array}$ & $\begin{array}{l}2.0 \\
2.0\end{array}$ & $\begin{array}{l}1.0 \\
2.0\end{array}$ \\
\hline \multicolumn{3}{|c|}{$\begin{array}{l}\text { Control } \\
\text { Herbicide } \times \text { species } \times \text { surfactant } \quad d f=6\end{array}$} & $\begin{array}{c}1.0 \\
\mathrm{P}<0.001\end{array}$ & $\begin{array}{c}1.0 \\
\mathrm{LSD}=1\end{array}$ & 1.0 & 1.0 \\
\hline
\end{tabular}

${ }^{1}$ Visual assessment based on a scale of $1=$ no effect to $10=$ complete kill.

${ }^{2} \mathrm{LSD}(\mathrm{P}<0.05)$ is for comparing means within a column with the respective control. 

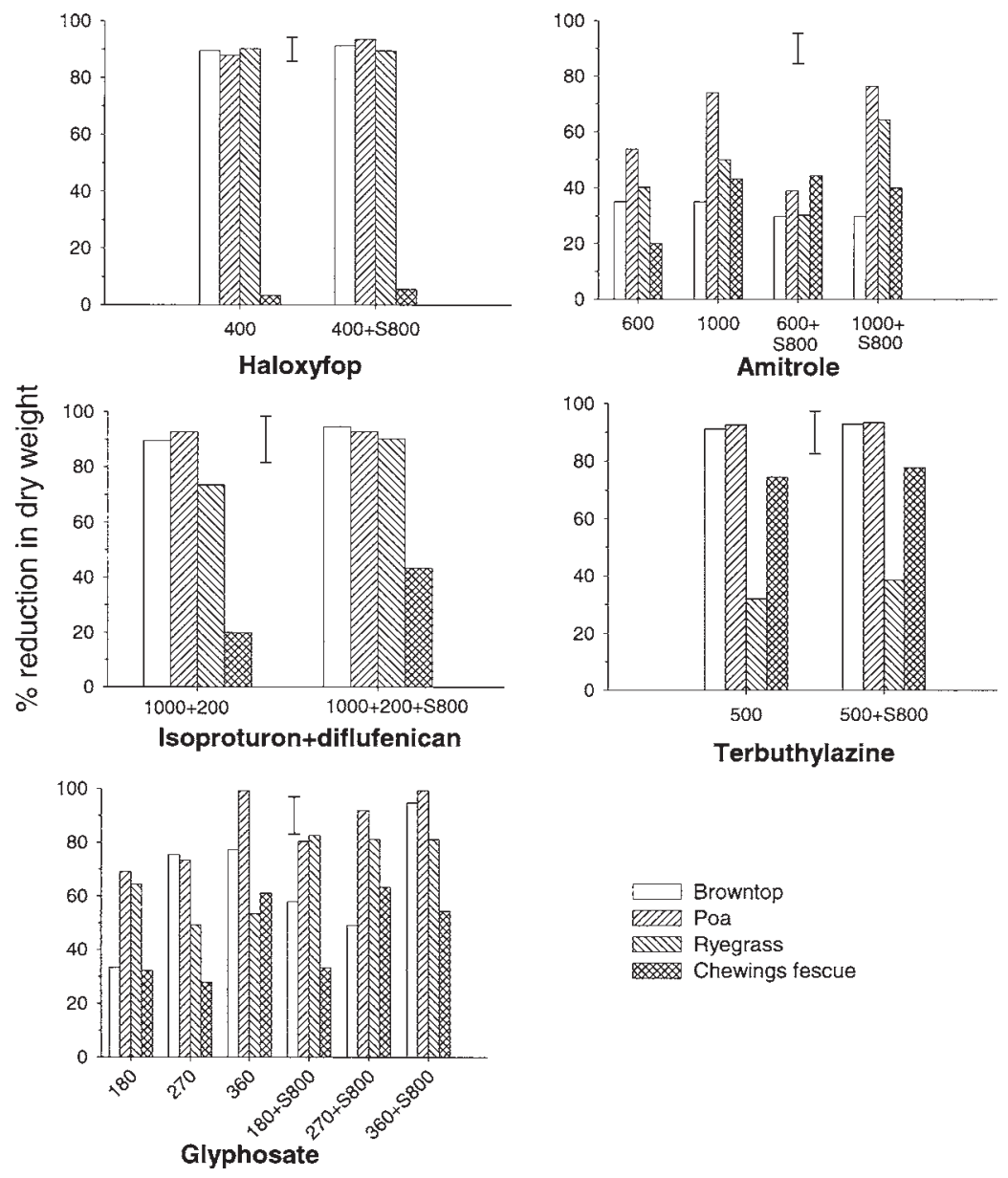

FIGURE 1: Effect of different herbicides with and without the organosilicone surfactant 5800 on the percent reduction in the dry weight of browntop, annual poa, perennial ryegrass and Chewings fescue in experiment 2 . Herbicide rates given under the bars are in $\mathrm{g}$ ai/ha. Error bars are LSD $(\mathbf{P}<0.05)$.

\section{Experiment 2}

Haloxyfop markedly reduced the dry weight of all grass species except that of Chewings fescue (Fig. 1). It appears that haloxyfop with or without surfactants may be a useful herbicide in a Chewings fescue lawn. Amitrole application at $600 \mathrm{~g} / \mathrm{ha}$ caused only mild damage to the grass species tested. At $1000 \mathrm{~g} / \mathrm{ha}$ this herbicide caused $74 \%$ reduction in the dry weight of annual poa with $35 \%$ and $43 \%$ reduction in the dry weight of browntop and Chewings fescue, respectively. The effect of isoproturon plus diflufenican on its own was more pronounced on annual poa than on perennial ryegrass or Chewings fescue (Fig. 1). However, the difference was not large enough to allow selective control of annual poa in these species. When S800 was added to isoproturon plus diflufenican all grass species showed more than $90 \%$ reduction in their dry 
weights. Terbuthylazine caused $93 \%$ reduction in the dry weight of annual poa but only $32 \%$ reduction in the dry weight of perennial ryegrass. In the absence of S800, glyphosate at $180 \mathrm{~g} / \mathrm{hacaused} 70 \%$ reduction in the dry weight of annual poa compared with only $33 \%$ reduction in the dry weight of browntop and Chewings fescue (Fig. 1). At $270 \mathrm{~g} / \mathrm{ha}$, glyphosate damage to browntop increased to $75 \%$ whereas the reduction in the dry weight of Chewings fescue was only $28 \%$. Annual poa was more sensitive to glyphosate compared to the other grass species and the highest rate of glyphosate caused more than $99 \%$ reduction in its growth. However, other turf grasses were sensitive to this rate as well. Addition of S800 to glyphosate at $180 \mathrm{~g} / \mathrm{ha}$ increased its effect on all grass species except Chewings fescue. This species did not respond to $\mathrm{S} 800$ at the high rate $(360 \mathrm{~g} / \mathrm{ha})$ of glyphosate.

\section{Experiment 3}

This experiment aimed to find the best combination of glyphosate rate and surfactant concentration for the control of annual poa. In the absence of surfactants, increasing glyphosate rate resulted in significant reductions in the dry weight of annual poa (Table 2 ). Glyphosate at $180 \mathrm{~g} / \mathrm{ha}$ caused only $77 \%$ reduction in the dry weight of annual poa but the addition of L77 increased this to more than $94 \%$ irrespective of the surfactant concentration. Similarly, addition of S800 to the lowest glyphosate rate caused significant increases in the control of annual poa. However, with this surfactant there was a positive response to increasing surfactant concentration from 0.1 to $0.25 \%$. Addition of organosilicone surfactants to glyphosate at $270 \mathrm{~g} / \mathrm{ha}$ did not affect its efficacy. At $360 \mathrm{~g} / \mathrm{ha}$, there was a significant reduction in the control of annual poa when L77 was added and the addition of S800 did not affect the performance of glyphosate.

TABLE 2: Effect of glyphosate at three rates in combination with two organosilicone surfactants, $\mathbf{L 7 7}$ and $\mathbf{S 8 0 0}$, on the growth of annual poa in experiment 3 . Values are percent reduction in dry weight compared to the untreated control.

\begin{tabular}{lccccccr}
\hline & & \multicolumn{7}{c}{ Surfactant } \\
$\begin{array}{l}\text { Glyphosate } \\
\text { g ai/ha }\end{array}$ & Nil & L77 & L77 & L77 & S800 & S800 & S800 \\
\hline \multirow{2}{*}{180} & 76.9 & 97.2 & 99.3 & 94.4 & 82.5 & 98.6 & 98.6 \\
270 & 92.3 & 90.9 & 91.6 & 94.4 & 94.4 & 99.3 & 88.8 \\
360 & 97.2 & 86.7 & 88.8 & 90.9 & 99.3 & 99.3 & 99.3 \\
& & \multicolumn{7}{c}{ LSD $=4.1^{1}$} \\
\hline
\end{tabular}

${ }^{1} \mathrm{LSD}(\mathrm{P}<0.05)$ is for comparing any two means within the table.

\section{DISCUSSION}

The first experiment identified a number of herbicides with some degree of selectivity in turf. Haloxyfop, fluazifop, clethodim and sethoxydim belong to the aryloxyphenoxypropionate group and are developed as grass killers. Chewings fescue exhibited a high degree of tolerance to these herbicides irrespective of the rate or the addition of surfactants. For control of annual poa in Chewings fescue, haloxyfop would be the best option of the herbicides tested, although clethodim at $240 \mathrm{~g} / \mathrm{ha}$ plus S800 was also an effective treatment (Table 1).

Ethofumesate damaged Chewings fescue more than other grass species tested. Perennial ryegrass and browntop showed tolerance to this herbicide, but annual poa was not controlled (Table 1). Ethofumesate has been used in parts of the United States and UK to manage annual poa where split applications and freezing temperatures following the application weaken annual poa (Baldwin 1993; Vargas 1990). In our experiment warm temperatures in the greenhouse probably helped the rapid recovery of annual poa from the herbicide damage. Moreover, it seems that ethofumesate kills only the annual biotype (Роа аппиа var. аппиа). However, in closely mown turf the 
perennial form (Pоа апnиа var. reptans) dominates and this biotype was used in our experiment.

All grass species exhibited high level of tolerance to the herbicide isoproturon and to the mixture isoproturon plus diflufenican at the lower rate used (data not presented), while at the higher rate promising differential tolerances were observed between species. Thus Chewings fescue was tolerant to the high rates of both these herbicides irrespective of the surfactant addition, perennial ryegrass was completely killed in the presence of L77 and annual poa was controlled by isoproturon plus diflufenican with the addition of either surfactant (Table 1). This is consistent with a previous report that the foliar activity of isoproturon was enhanced by adjuvants (Mathiassen et al. 1993). In the second experiment, there was not an adequate selectivity margin between the species to allow safe use of isoproturon plus diflufenican in turf (Fig. 1). On the basis of these results it appears that additional testing at intermediate rates with surfactants would be required.

Irrespective of the surfactant addition, browntop exhibited high tolerance to the sulfonylurea herbicides chlorsulfuron and metsulfuron while perennial ryegrass was sensitive to them (Table 1). While neither herbicide could be recommended for annual poa control, they could nevertheless be used to remove perennial ryegrass from browntop turf. This has application on many golf course roughs and fairways that have been developed from farmland where mowing costs would be reduced because perennial ryegrass grows much more quickly than browntop and thus needs more mowing.

In the first experiment amitrole was used at 120 and $200 \mathrm{~g} / \mathrm{ha}$ and a high level of tolerance was observed with all species. In the second experiment, amitrole caused $54 \%$ and $74 \%$ reduction in the dry weight of annual poa at rates of 600 and $1000 \mathrm{~g} / \mathrm{ha}$, respectively (Fig. 1). At the high rate, damage to browntop and Chewings fescue was $35 \%$ and $43 \%$ only. This damage was further reduced when S800 was added to the herbicide. These results showed that amitrole might have potential in weed management in turf and further experiments are required to determine the optimum herbicide rate and surfactant concentration for selective control of annual poa.

The first and the second experiments showed that annual poa was more sensitive to glyphosate than the other species tested and that increasing glyphosate rate from 180 to $360 \mathrm{~g} / \mathrm{ha}$ increased the damage to annual poa. At $360 \mathrm{~g} / \mathrm{ha}$ glyphosate caused serious damage to browntop, perennial ryegrass and Chewings fescue (Fig. 1). It follows that only low rates of glyphosate ( $180 \mathrm{~g} / \mathrm{ha}$ and less) should be considered for the control of annual poa in turf. When $\mathrm{S} 800$ was added to glyphosate at $180 \mathrm{~g} / \mathrm{ha}$ there was $80 \%$ reduction in the dry weight of annual poa while Chewings fescue continued to show only $33 \%$ reduction in its dry weight. Previous work has also reported that the interaction between organosilicone surfactants and glyphosate is species dependent (Dastgheib and Field 1995; Field et al. 1992). The best control of annual poa at 180 $\mathrm{g} /$ ha glyphosate was obtained with the addition of $\mathrm{L} 77$ at $0.25 \%$ concentration (Table 2). It appears that further experimentation with organosilicone surfactants may determine the optimum treatment for selective control of annual poa in Chewings fescue and browntop turf.

\section{ACKNOWLEDGEMENTS}

We wish to thank Peter Macintosh of Hagley Golf Club, Mike Thomas of Lincoln University, Karl Johnson of Lincoln Green and Keith Saulsbury of Wrightson Kimihia Research Centre for permission to take plant samples from their turf.

\section{REFERENCES}

Baldwin, N.A., 1993. Chemical control of Poa annua: a review. J. Sports Turf Res. Inst. 69: 7-19.

Beard, J.B., 1973. Turfgrass: Science and Culture. Prentice Hall, N.J. 658 pp.

Dastgheib F. and Field, R.J., 1995. Control of perennial grasses by glyphosate and the effect of additional surfactants. Proc. 4th International Symposium on Adjuvants for Agrochemicals: 409-414. 
Dastgheib F., Field, R.J. and Searle, H., 1994. Surfactant effects on uptake of different herbicides by gorse. Proc. 47th NZ Plant Protection Conf: 392-396.

Dernoeden, P.H., 1998. Use of prodiamine as a preemergence herbicide to control annual bluegrass in Kentucky bluegrass. HortSci. 33: 845-846.

Fagerness, M.J. and Penner, D., 1998. Evaluation of V-10029 and trinexapac-ethyl for annual bluegrass seedhead suppression and growth regulation of five cool-season turfgrass species. Weed Tech. 12: 436-440.

Field, R.J. and Bishop, N.G., 1988. Promotion of stomatal infiltration of glyphosate by an organosilicone surfactant reduces the critical rainfall period. Pesticide Sci. 24: 55-62.

Field, R.J., and Dastgheib, F., 1996. Enhancing uptake and translocation of systemic active ingredients. Pp 241-295 In: Pesticide Formulation and Adjuvant Technology, C.L. Foy and D.W. Pritchard (Eds); CRC Press, Florida.

Field, R.J., Dobson, N.N. and Tisdall, L.J., 1992. Species-specific sensitivity to organosilicone surfactant-enhancement of glyphosate uptake. Pp 423-431 In: Adjuvants for Agrichemicals, C.L.Foy (Ed); CRC Press, Florida.

Fussell, A. and Walton T., 1997. New Zealand Agrichemical Manual. Wham Chemsafe Ltd. Wellington.

Gaskin, R.E., and Zabkievicz, J.A., 1992. Effect of plant age and adjuvant on the foliar penetration of glyphosate in pampas grass. Pp. 405-409. In: Adjuvants for Agrichemicals, C.L.Foy (Ed); CRC Press, Florida.

Glasgow, A., 1991. Poa annua control in ryegrass sportsfields, cricket wickets, green surrounds and tees using herbicides. NZ Turf Management J. 5: 9-11.

Goss, R.L., Brauen, S.F. and Orton, S.P., 1975. The effects of N, P, K, and S on Poa апnиа L. in bentgrass putting green turf. J. Sports Turf Res. Inst. 51: 74-82.

Johnson, B.J. and Murphy, T.R., 1996 Suppression of a perennial subspecies of annual bluegrass (Poa annua spp. reptans) in a creeping bentgrass (Agrostis stolonifera) green with plant growth regulators. Weed Tech. 10: 705-709.

Mathiassen, S.K., Jensen, P.K., Kudsk, P. and Larsen, T.K., 1993. Possibilities for improving the foliar activity of isoproturon. Proc. Brighton Crop Protection Conf. 2: 585-590.

McLean, J.R.F., 1978. Control of poa annua in fine turf using ethofumesate.Proc. 31st NZ Weed and Pest Control Conf:: 192-194.

Vargas, J.M., 1990. Myths and truths about annual bluegrass. NZ Turf Management J. 4: 9-11. 